\title{
ASSESSMENT OF THE EUROPEAN COMMISSION INITIATIVES ON CREATING TRANSNATIONAL MEDIA NETWORKS
}

\author{
Dr. Elena Kaliberda ${ }^{1}$
}

\begin{abstract}
The paper examines two European Commission initiatives on creating transnational media networks on European affairs, the Euronews television and the Euranet Plus radio network, and their roles in the European public sphere. An overview of Euronews and Euranet Plus is based on the author's research, first-hand contacts with representatives of the European Commission, media in Belgium and France, and field work at the editorial office of Euronews in Lyon-Ecully and at the editorial offices of Euranet Plus in Paris and Brussels.
\end{abstract}

Keywords: European public sphere, transnational media networks, Euronews, Euranet Plus.

\footnotetext{
${ }^{1}$ Elena Kaliberda holds a Master degree in Journalism and in European, Russian and Eurasian studies as well as a $\mathrm{PhD}$ degree in Philology. Currently she is pursuing a second $\mathrm{PhD}$ degree in Communication at Carleton University. She is a producer of the Russian language program at CHIN, a multicultural radio station in Ottawa, Canada.
} 


\section{Introduction ${ }^{2}$}

The purpose of the study is to consider the models of audiovisual media on European affairs which are supported by the European Commission and presented by Euronews television and the Euranet Plus radio network, as well as their roles in the European public sphere. The preliminary research indicated that since 2005 the European Commission encourages the creation of audiovisual media on European affairs in Europe. As a result, in 2007 a new European radio network was established.

Several findings made during the preliminary research became stimuli to proceed with a further study. First, the literature review showed that there is a large body of scholarship on the European public sphere and there are sources on TV and radio media, but usually they are not considered from the perspective of creating media networks with a European agenda. Second, radio, as a tool to help create a public sphere, is arguably understudied. For example, Euranet, a European radio network that has existed for over seven years, was not mentioned within the scholarly literature. Finally, although there are several works ${ }^{3}$ that consider the Euronews project as an example of transnational European media, they are now dated and consider it without referring to the public sphere concept. So, this study is an attempt to collect and to summarize information on the European Commission initiatives on the creation of transnational audiovisual media networks with a European agenda. It is the first attempt to subject the radio network Euranet Plus to a scholarly study and to compare two audiovisual media on European affairs created at the European Commission initiatives.

The main research question explores the purpose of Euronews and Euranet in relation to the European public sphere, and how the Euronews experience could affect the development of Euranet Plus, which is yet another transnational medium of European affairs. More specifically, I address the following research questions: Does Euronews represent, in part, an effort to foster the development of the public sphere? What kinds of answers are given to this question by European observers and by EU institutions? Was the fostering of the public sphere a motivation for the creation of Euranet Plus? Does Euranet represent, in part, an effort to foster the development of the public sphere? What kinds of answers are given to this question by European observers and by EU institutions? How did the experience with Euronews affect the development of Euranet? Was there institutional learning?

The main hypothesis of this study is that Euronews and Euranet Plus, as audiovisual transnational media, represent an effort to foster the development of the European public sphere. Another part of the hypothesis is that Euronews provided institutional learning for Euranet Plus with the European Commission as the vehicle.

The theoretical framing of the issue relies on the theory of the European public sphere. The methodology relies on an analysis of primary and secondary sources. The primary sources

\footnotetext{
${ }^{2}$ I am grateful to Prof. Joan DeBardeleben for reviewing the final version of the article and offering valuable suggestions, as well to the two anonymous experts for their helpful comments and constructive critiques.

${ }^{3}$ For example see Brüggemann 2008; Garcia-Blanco \& Cushion 2010; Eriksen 2007.
} 
include the European Commission policy documents, directives and Eurobarometer public opinion surveys. Research interviews conducted in Belgium and France with members of Euronews television and Euranet Plus radio, European journalists and representatives of the European Commission (in total there are 10 interviews) are the main empirical material of this research. The qualitative research is the main method applied within this study. The method of comparative studies is also applied to analyze the similarities, advantages and disadvantages of television and radio initiatives.

\section{Theorizing the European public sphere}

A large number of scholarly publications discuss the European public sphere and the role of media. ${ }^{4}$ In particular, many scholars agree that the pioneer researcher of the European public sphere was Habermas who "made the principal assumptions on the concept of the public sphere" (Harrison \& Wessels 2009, 131). Habermas stated in 1960 that the public sphere is "a sphere between civil society and the state" (McCarthy 1989). Habermas 5 also concluded that "the usage of the words 'public' and 'public sphere' betrays a multiplicity of concurrent meanings... Events and occasions are public when they are open to all..." (ibid, 1). So, from this perspective it is possible to conclude that one of the mechanisms to make events open for everyone is to ensure their publicity and to provide opportunities for ordinary citizens to participate in discussions and decision-making.

A review of published sources revealed a wide variety of perspectives on the development of the European public sphere, and the role of media and institutions. While there are numerous definitions of the European public sphere within the literature, a key common point is that the public sphere is defined as a communicative space that provides equal opportunities for all actors in the process of sharing public opinion. This communicative space can be "social", "European", and "transnational". ${ }^{6}$ Communicative spaces can be organized in the form of a network, media network, forum, public debate (Eriksen 2007, 23; Harrison 2009, 9), and as a discussion (Heller \& Renyi 2007, 173). The structures of the European public sphere include: political and social clubs (Eriksen 2007), think tanks, media, national and transnational NGOs which organize debates, forums, discussions, public protests, letters, communiques. Based on the definition of the European public sphere and the ability of media to involve a large audience of Europeans in the process of sharing public opinion, the media can be considered an important element of the European public sphere.

\footnotetext{
${ }^{4}$ The following authors discuss the European public sphere and the role of media: Baisnee 2007; Bentele \& Nothhaft, 2010; Brüggemann \& Schulz-Forberg 2008; Butsch 2007; Chalaby 2002; Eriksen 2005 and 2007; Firmstone 2008; Fraser 2007; Garcia-Blanco \& Cushion 2010; Gripsrud 2007; Grundmann 1999; Harrison \& Wessels 2009; Heller \& Renyi 2007; Kaitatzi-Whitlock 2007; Kantner 2006; Lauristin 2007; Lecheler 2008; Machill \& Beller 2006; Metykova \& Preston 2009; Papathanassopoulos \& Negrine 2011a and 2011b; Peters et al. 2005; Raupp 2004; Statham 2011; Trenz 2007 and 2008; Veltri 2012; Venturelli 1993; Volkmer 2008; Wessler \& Brüggemann 2007.

${ }^{5}$ I am referring here to the 1989 edition of his classical 1960 publication.

${ }^{6}$ The European public sphere is described by various scholars as "a social room" (Eriksen 2007, 23),

"a socio-spatial extension" (Wessler \& Brüggemann 2007, 96), "a European transnational communication space" (Brüggemann \& Schulz-Forberg 2008, 78), "a communicative space within which conversations and discussions ('democratic deliberations') take place" (Papathanassopoulos \& Negrine 2011a, 128), "a truly inter- or transnational shared space where those holding political and bureaucratic power confront a well-informed, critical public" (Gripsrud 2007, 480).
} 
The European public sphere has been researched by scholars because it is significant for European integration. Several scholars point out the role of the European public sphere in relation to the creation of a European identity, and the creation of a European "demos" to reinforce democratic legitimacy. ${ }^{7}$ An objective of the EU is the creation of a unified and strong European Community. Presently, the EU faces several problems that are connected with the lack of the feeling of togetherness of European citizens which is often characterized by scholars as a lack of a European identity. ${ }^{8}$ The first issue is that European citizens do not feel that they share a common sense of belonging to the European Union. These results were reflected in the Eurobarometer surveys EB 73-80 from May 2010 to December 2013. According to the Eurobarometer-survey in May 2012, "citizens of the different Member States feel very differently about the European Union" (PoliPedia.eu 2014). The second issue is that the EU citizens' knowledge of the EU is very basic. ${ }^{9}$

How can a European identity be achieved? There are some models that were identified in the scholarly literature. The media with a European agenda can impact the public perception of themselves as Europeans. ${ }^{10}$ In the viewpoint of Brüggemann and Schulz-Forberg (2008), the media can help in strengthening the concept of the collective identity, and some media are actively involved in this process, e.g. Euronews and the European Voice. Citizen participation in the European project is a necessity for the functioning of the European Union unity. According to Eriksen (2007), democratic legitimacy can be achieved by public debates. In the point of view of Kaitatzi-Whitlock $(2007,696)$, European citizens have to be heard, to express opinions, "to fulfill their active information/"communication rights"'.

In summary, the European public sphere is important for identity, democratic legitimacy, support of the EU and European integration. Finally, the European public sphere is aimed at helping promote solidarity amongst citizens by creating a supranational political community.

\section{The European media in creating the European public sphere}

According to Harrison and Wessels $(2009,131)$, the networked structure of the European public sphere is "composed by different actors such as civil-society organizations, relays, media infrastructures which interact with different institutions not only within the EU but also on national, regional and local levels". Although the media by itself might not necessarily be an initiator of debates, media can play a passive role as a one-way provider of information without receiving any feedback from citizens; scholars nonetheless pointed out the central role of media in the European public sphere. ${ }^{11}$

Five functions can be attributed to the role of media in the European public sphere. The first function is a formation of a European identity. This point of view is supported by Kantner (2006,

\footnotetext{
${ }^{7}$ Gripsrud (2007), Eriksen (2005), Kantner (2006), Papathanassopoulos and Negrine (2011b), Statham (2011).

${ }^{8}$ Papathanassopoulos and Negrine (2011b) and Statham (2011).

${ }^{9}$ Grundmann (1999) and Preston (2009).

${ }^{10}$ Papathanassopoulos and Negrine (2011a), Wessler and Brüggemann (2007), Eriksen (2007), Bee (2008).

${ }^{11}$ The following authors consider media as institutional infrastructures of the European public sphere: Harrison \& Wessels 2009; Metykova \& Preston 2009; Nieminen 2008; Trenz 2008. In point of view of Raupp (2004), media is a large arena of the European public sphere.
} 
512) who stated that "the transnational mass media agenda of common European policy issues reinforces the awareness of 'being in the same boat'". The second function is the formation of public opinion. According to Trenz (2007), media is a generator of ideologies. Papathanassopoulos and Negrine believe that "the media do play a significant role in creating the context for the development of perceptions about things European" (2011a, 124). The third function of a fulfillment of democratic norms and citizens' engagement can be implemented through the publications or participation in the television and radio programs. Media facilitate a connection between EU institutions and their publics, ${ }^{12}$ and provide "the freedom to express ideas publicly" (Eriksen 2007, 32). The fourth function of media in the European public sphere is ensuring transparency in the decision-making of EU-institutions'. From Statham's perspective, the main interpreter of the European content making is the fact that the "European decisionmaking has to be visible to citizens" (Statcham 2011, 80). Finally, the function of media in the European public sphere is informing the public on European affairs. Trenz $(2007,89)$ stated that the media of the European public sphere could be identified as a European news cover.

For purposes of European integration, transnational media are particularly important and play a significant role. While there are numerous definitions and discussions of transnational media, the key notion of this definition is media that simultaneously covers EU affairs in several Member States and broadcasts in different languages. ${ }^{13}$ In contrast, "Europeanized" media devotes more time and space to news on European affairs (Garcia-Blanco \& Cushion 2010 - one example of Euronews), but do not necessarily broadcast or distribute their programming in more than one Member State. Transnational media can be national media with a transnational mission, international with a European agenda, pan-regional, or global media (Brüggemann \& SchulzForberg 2008, 78). Some of them, such as Euronews and BBC, broadcast beyond the European public sphere, but remain transnational media in terms of the EU. Some scholars argue that transnational media play a significant role in the European public sphere and in European integration. ${ }^{14}$ Transnational audiovisual media are considered in the literature as a powerful tool to reach a large audience, to influence the public opinion, to create a common information space, to form a European identity, and to establish dialogue between EU institutions and their citizens.

\section{The European Commission's initiatives on creating transnational media}

Many authors ${ }^{15}$ have referenced efforts of the European Union ${ }^{16}$ to create a European public sphere. The European Commission produced the major European Union legislative normative

\footnotetext{
${ }^{12}$ Kevin 2003; Neidhardt et al. 2000; Schlesinger 1999; Schlesinger \& Kevin 2000 in Firmstone 2008.

${ }^{13}$ I formulated this definition based on descriptions of a transnational media in the European public sphere given by Bee (2008), Brüggemann and Schulz-Forberg (2008), Chalaby (2002), Eriksen (2007), Firmstone (2010), Gardoso (2008), Gripsrud (2007), Harrison and Wessels (2009), Kaitatzi-Whitlock (2007), Lecheler (2008), Nieminen (2008), Papathanassopoulos and Negrine (2011a), Statham (2011), Thiel (2008), Veltri (2012).

${ }^{14}$ Garcia-Blanco \& Cushion (2010), Firmstone (2008), Grundmann (1999).

${ }^{15}$ The following authors discuss the role of the EU institutions in the development of the European public sphere: Baisnee 2007; Bee 2008; Brüggemann and Schulz-Forberg 2008; Chalaby 2002; Eriksen 2007; Fraser 2007; GarciaBlanco and Cushion 2010; Gardoso 2008; Harrison and Wessels 2009; Heller and Renyi 2007; Kohler-Koch and Eising 1999; Lauristin 2007; Metykova and Preston 2009; Nitoiu 2013; Papathanassopoulos and Negrine 2011a and 2011b; Raupp 2004; Statham 2011; Thiel 2008; Trenz 2007 and 2008; Veltri 2012; Venturelli 1993; Volkmer 2008; Wessler and Brüggemann 2007.

${ }^{16}$ Here I am referring to efforts of the main EU institutions such as the Council of Europe, the European Parliament, and the European Commission.
} 
documents that included efforts to contribute to a communicative space where citizens participate in decision-making. An analysis of Treaties and European Commission policy documents reveals that the European public sphere has been on the agenda of policy documents since 1992. As stated in the White Paper on a European Communication Policy (2006), the communications gap between the EU and its citizens has been a subject of discussion in EU circles at least since the referenda that preceded the entry into force of the Maastricht Treaty in 1992. At that time that the EU took steps towards improving the transparency of its institutions, the collaboration of EU institutions in public information, providing more opportunities for citizens' debates, creating a closer union of people, and the creation of a political union. By 2015 the EU achieved significant progress in these directions.

The goal of the European Commission to support trans-European media - such as Euronewshas changed over time. In 1992, the initial the purpose was to foster the development of European digital video services, whereas since 2005 the Commission's goal is to support broadcasting news with a European agenda. The Plan-D (EC 2005) became the first working document that was aimed at promoting wide-range debates and provided financial opportunities for the development of transnational TV and radio networks on European affairs. The implementation of the EU communication strategies brought up the necessity of developing a new model of inter-institutional cooperation in the area of communication and transparency, and of new communication structures of the European Commission and Representatives of the EU in the Member States. Communications also became a part of the EU's regional policy.

In 2005, the European public sphere became a more prioritized topic because of the decrease of trust in European institutions and the rise of Euroscepticism. The creation of transnational media networks began in 2007, since the Lisbon Treaty. The Communicating Europe in Partnership (2007a) is one of the most important strategic policy documents of the European Commission on creating transnational audiovisual media with European agenda. The document contains a European Commission decision which finds its further implementation in the ensuring documents: "The Commission will contribute to greater and more sustainable coverage of EU affairs on existing audiovisual channels, and encourage European networking by broadcasters" (EC 2007a, 11). In general, this policy document brought new opportunities in sponsoring radio and TV programs on European affairs (EC 2007a). In 2008, the paper Communicating Europe through Audiovisual Media was adopted by the European Commission as a follow-up to Communicating Europe in Partnership. This paper (EC 2008a) together with the Internet Strategy (EC 2007b) is aimed to realize the Commission decision stated in the Communicating Europe in Partnership strategy to support networks of EU-content broadcasters. It is aimed at supporting existing networks of EU-content broadcasters and the creation of new networks.

In the following sections, I will consider the institutional models of Euronews and Euranet Plus, and their roles in the European public sphere based on my interview findings and field work. This primary research serves a broader goal, which is to compare these institutional models of transnational media with a European agenda. 


\section{Euronews}

The Euronews television channel was established by broadcasters from 10 European countries in 1992 and started broadcasting in 1993. Its shareholders structure has changed during the last twenty years, and as of 2016 it is currently owned by 21 public television channels and three 3 local authorities. ${ }^{17}$ Euronews has European shareholders and those that are outside of Europe. As a European Commission source mentioned, "Euronews broadcasts [are] not only for Europe but also [go] beyond the European public sphere" ${ }^{18}$, to give them global coverage. It is possible to watch Euronews using satellite antennas in 155 countries around the world, including in Europe, Russia, Asia/Pacific, Middle East and Africa, Central and South America, and North America. Recently, Euronews opened a bureau in Washington (United States). Euronews' main headquarters is in Lyon, France; but it also has bureaus and journalists working in Brussels, national bureaus in Kiev (Ukraine), Budapest (Hungary) and also in Athens (Greece). Presently, Euronews broadcasts in 13 languages: Arabic, English, French, German, Greek, Hungarian, Italian, Persian, Polish, Portuguese, Russian, Spanish, Turkish, and Ukrainian.

Denis Loktev, a senior producer of Euronews, pointed out that it is not a network but a transnational TV channel that has editorial offices. According to Loktev, the role of Euronews as a transnational media in creating the European public sphere is to help citizens "living in different countries to communicate with each other, because they need to know what happens in other countries than theirs". ${ }^{19}$ According to Loktev, the lack of information on the European integration project and the fact that citizens only get news from national media leads many citizens feeling that "something is happening behind their backs. They do not really understand the European Union, they do not get a clear idea of what it is and why they need to support it". In order to change this situation, "what needs to be done is better informing people and better interaction. People need to be able to learn more about the European integration project and to participate more, to talk directly to people living in other countries, to discuss different topics of integration and to feel this is something they want and need". Loktev pointed out that "Euronews was created to cover global news, primarily European news from a common European viewpoint as a counterpoint to the national viewpoint". Loktev concluded that "Euronews is the only TV channel that broadcasts news about Europe from the European view point in 13 languages, most European languages, it is a good example of how it can be done". ${ }^{20}$

Albina Lir, a strategic planning editor of Euronews, pointed out that the role of Euronews is in explaining what is going on in Europe. The problem that citizens face is "everything that European institutions decide is very difficult to understand because European citizens are really far from that. They have their own lives, but decisions made in Brussels affect them. Euronews is

\footnotetext{
17 Euronews shareholders are CT (Czech Republic), CyBC (Cyprus), ENTV(Algeria), ERT (Greece), ERTT (Tunisia), ERTU (Egypt), France Télévisions (France), NTU (Ukraine), PBS (Malta), RAI (Italy), RTBF (Belgium), RTE (Ireland), RTP (Portugal), RTR (Russia), RTVSLO (Slovenia), SNRT (Morocco), SSR (Switzerland), TRT (Turkey), TVR (Romania), TV4 (Sweden), YLE (Finland), Grand Lyon, Département du Rhône, Région RhôneAlpes.

${ }^{18}$ Interview with a source in the European Commission, in conversation with author, Brussels, Belgium, 26 May 2014.

${ }^{19}$ Interview with Denis Loktev (a senior producer of Euronews), in conversation with author, Lyon, France, 30 May 2014.

${ }^{20}$ Ibid, 2014.
} 
a kind of bridge to talk with European institutions to understand the results of what they decide and how it will impact Europe and people living in Europe". ${ }^{21}$ According to her, Euronews produces two types of news: one explains news events to Europeans and the other tells what Europe already thinks about various events. Lir mentioned that "the idea of Euronews is to expand broadcast languages up to 24 . Euronews presents many cultures, it gives an opportunity to viewers to learn about different countries and in some sense it plays an educational role". According to her, the role of Euronews is "to be objective, to try to inform Europeans on what is going on not only in Brussels and European institutions but in the European countries as well". ${ }^{22}$

The deputy editor in chief of Euronews Stéphane Parizot explained that the goal of Euronews is to provide news but also to explain what Europe is, to make this concept easier to understand. Sometimes coverage news on European affairs can be boring. Euronews tries "to translate it in European language in simple words". ${ }^{23} \mathrm{He}$ also pointed out that "if we manage to explain what is the real Europe, if we manage to make people understand what it is, this type of media could be considered as helpful for the European integration". Parizot pointed out that Euronews changed an editorial line a few years ago to become "the first channel starting to broadcast debates of the European Commission candidates". ${ }^{24}$ In 2014, for the first time in the history of the European Parliament elections, European voters could directly elect the President of the European Commission. Euronews held live debates broadcasted in 13 languages.

Augustin Palokaj, the chief of the Croatian newspaper Jutarhji List bureau in Brussels, ${ }^{25}$ also noticed that Euronews recently started organizing debates to invite analysts to discuss the issues they present. The large neon-lit studio of Euronews was placed at the central hallway of the European Parliament in Brussels on the election night on May 26, 2014. Palokaj noted that

Euronews was the only TV channel to cover European elections from a European point of view. For example, if we turned on the BBC channel, [there would be] coverage of the European elections only reporting from the British angle: how a UK party won most of the votes, what will be the role of the UK in the future of the European Union, how will these results reflect UK relations with the rest of the European Union, and so on. It was the same with the German and Spanish TV channels and other national television channels. Euronews was the only channel to provide a broader European picture. ${ }^{26}$

Palokaj concluded that this time was different because, "during the debates on the eve of the European Parliament elections, Euronews was pretty balanced because they had in the studio different analysts, they had interviews with the main presidential candidates representing various political parties. They also interviewed people from different parties and were even publishing

\footnotetext{
${ }^{21}$ Interview with Albina Lir (a strategic editor of Euronews), in conversation with author, Lyon, France, 30 May 2014.

${ }^{22}$ Ibid, 2014.

${ }^{23}$ Interview with Stéphane Parizot (the deputy editor in chief of Euronews), in conversation with author, Lyon, France, 30 May 2014.

${ }^{24}$ Ibid, 2014.

${ }^{25}$ Interview with Augustin Palokaj (the chief of Croatian newspaper Jutarhji List bureau in Brussels), in conversation with author, Brussels, Belgium, 26 May 2014.

${ }^{26} \mathrm{Ibid}, 2014$. For the benefit of the reader, the syntax of this quote was lightly edited.
} 
feeds ${ }^{27}$ from the viewers" ${ }^{28}$ As was pointed out by Lir, this was the first time when Euronews was so well represented in Brussels (a studio in the Brussels office and a studio in the European Parliament). ${ }^{29}$ The choice of speakers showed that Euronews gave an opportunity to speak out mostly to representatives of civil society, journalists and bloggers and independent analysts. They also placed an emphasis on the coverage of the youth vote.

These interviews suggest that the role of Euronews in the European public sphere is to: create a supranational point of view, explain to Europeans what is going on in neighbouring countries, develop a feeling among Europeans that the EU is their common unity, discuss different topics about the European integration, raise discussion and ensure more transparency the EUinstitutions. The Euronews bureau in Brussels which opened in June 2011, serves these goals. All interviewees agreed that the opening of a bureau in Brussels brought many innovations to the Euronews structure, which has allowed the channel to strengthen its cooperation with EU institutions and to produce more news on European affairs.

As it was claimed by Euronews in 2014, "Euronews' worldwide distribution has nearly doubled in the last 5 years and the channel continues its global expansion, now covering all 5 continents". The channel is viewed within households, hotels, and on board major airlines, Euronews displays in busy places, and in colleges and universities (Ibid). Among many public places, Euronews broadcasts its latest news at: NATO, EU and European Commission headquarters in Brussels and Strasbourg; shareholders Brussels train stations; the French Parliament in Paris, international airports in Kiev, Tunis, Bucharest, Istanbul; and within media companies like Le Figaro Newspaper in France or the OMD media agency in London (Euronews, 2014). According to the Q1 2014 Euronews distribution report, Germany holds the largest number of household viewers (30 million), followed by France (23 million), and the UK (16 million). In Russia, there 17 million household viewers. On the other hand, there are 4 million household viewers in Belgium, 1 million in Greece and Ireland, and 7 million in the Netherlands and in Italy respectively.

Over time, the target audience of Euronews has thus been expanded. In an effort to prioritize youth viewership, Euronews launched the Euronews Campus in February 2014. This program was aimed to organize live broadcasting in prestigious universities worldwide. Euronews has secured partnerships with several universities in Europe - Belgium (Vesalius College, Brussels School of Journalism and Communications), Cyprus (Cyprus University of Technology), France (EnLyon Business school) and also in Egypt (Future University in Egypt), New Zealand (University of Auckland) and Turkey (Marmara University) with more than 130,000 students in total to ensure their awareness about European affairs. The Euranet Plus radio network was the next significant initiative of the European Commission to create an audiovisual transnational media on European affairs.

\footnotetext{
${ }^{27}$ Feeds are brief texts (comments) received from viewers through different mobile devices.

${ }^{28}$ Ibid, 2014.

${ }^{29}$ Interview with Albina Lir (a strategic editor of Euronews), in conversation with author, Lyon, France, 30 May 2014.
} 


\section{Euranet Plus}

The Euranet Plus radio network was the next significant initiative of the European Commission to create an audiovisual transnational media on European affairs. As was mentioned by several interviewees, the idea of launching a network of radio channels on European affairs came from the European Commission. A source in the European Commission also pointed out, "Euranet did not exist before the Commission call for tenders. Euranet is a private contractor but it is also a part of the Commission initiative". ${ }^{30}$ According to Jan Simmen, Management/Strategy Chief of Euranet Plus and a former member of the Euranet Consortium (2008 to 2012), the idea of creating a radio network was developed prior the European Parliament elections of 2009. ${ }^{31}$ The official mission of the network is to create awareness about European affairs, strengthen the understanding of European affairs, better inform citizens and to stimulate exchange of opinions and debates of European citizens on EU affairs. ${ }^{32}$

The institutional model of the Euranet radio network changed several times due to changing requirements of the European Commission. Euranet and Euranet Plus radio network are two projects that were awarded contracts by the European Commission in 2008 and in 2013.

Euranet - from 2008 to 2012 (the European Commission first tender, contract of DG Communications)

Euranet Plus - from 2013 to present (the European Commission second tender, contract of DG Communications)

Euranet Connect (Universities' radio) - from 2008 to 2012 (contract of DG Education and Culture)

Euranet Plus Connect (Universities' radio) - from 2013 to present (partly supported by the grant of DG Education and Culture and by the Euranet Plus news agency)

According to the Warsaw Declaration of Pan-European cooperation and communication (Polskie radio 2009), the Euranet Consortium ${ }^{33}$ was founded on 25 July 2007. From April 1, 2008 the Euranet network began broadcasting programs on European affairs in languages of the countries belonging to the European Union; this was the first time when the European Commission awarded a five-year contract to the Euranet Consortium. At the end of 2012 the European Commission decided not to renew the first service contract with Euranet but to launch a new tender for a new contract. The purpose of the call for tenders was "to develop the production and broadcast of regular, specifically dedicated radio programmes in different official EU languages,

\footnotetext{
${ }^{30}$ Interview with a source in the European Commission, in conversation with author, Brussels, Belgium, 26 May 2014.

${ }^{31}$ Interview with Jan Simmen (management and strategy chief of Euranet Plus), in conversation with author, Brussels, Belgium, 21 May 2014.

32 www.euranetplus-inside.eu

${ }^{33}$ Euranet is the generally used shorthand for the European radio network.
} 
at peak listening times by each member of a network of professional EU radio broadcasters" (Euroalert 2013). ${ }^{34}$

As a source in the European Commission stated, it was "a tender to renew not the project but the concept of the pan-European network of radios" ${ }^{\prime 3}$. In 2013 the contract based on the tender PO/2012-09/A6 "Production and broadcast of radio programmes on EU affairs, on air and on digital platforms, by a network of EU radio broadcasters" was awarded to Euranet Plus (Euroalert 2013). However the conditions of the contract were changed. According to this second call for tenders, to join the network a radio has to satisfy the criteria that are include within the technical specification of the contract: to have 300,000 listeners per day or to a 5 percent share of the national market and to broadcast news with European perspective no less than 75 minutes per week (the initial Euranet had no conditions). ${ }^{36}$

The editorial line of Euranet Plus was also changed by the second contract with the European Commission. Previously there was no definition of European news. The main goal of Euranet Plus is now to cover stories which are related to the European agenda and European policies and to the activities of EU institutions. The main point of the Euranet Plus new editorial line is stated as follows: "The goal of the network is to produce together European stories directly related to European policies and the European agenda", as explained Dominique D'Olne, the Chief operating officer for Editorial content of Euranet Plus. ${ }^{37}$ According to D'Olne, at the beginning of the contract Euranet was supposed to be used for building the European public sphere. Telling the audience stories about what was happening in other EU countries was their main contribution to the development of the European public sphere. ${ }^{38}$ This mandate is expressed in the European Commission document (EC 2008b): "to bring the European Union and its citizens closer together".

Euranet Plus members do many interviews with citizens from other EU countries, not only from the country of broadcasting. D'Olne explained the importance of this type of coverage: "It is important to make listeners aware that Europe is not only a question of national interest of 28 partners. It is a task of journalism to show that there are some European issues that are not of national interest". ${ }^{39}$ Mareike Roewekamp, a Project Manager of the Administrative office of Euranet Plus, stated that the promotion of the exchange of opinions and debates is a part of the mission of Euranet Plus. ${ }^{40}$ In particular, each Euranet Plus radio station has programs that are called talk-shows which engage citizens in debates, ask for their opinions. ${ }^{41}$ An interview with people on a street is also a way of asking opinions. Some members have online tools for the exchange of opinions. Euranet Plus also conducts a monthly debate series, Citizens' Corner,

\footnotetext{
${ }^{34}$ Euroalert.net is a website publishing European Union grants and calls for proposals.

${ }^{35}$ Interview with a source in the European Commission, in conversation with author, Brussels, Belgium, 26 May 2014.

${ }^{36}$ Ibid, 2014.

${ }^{37}$ Interview with Dominique D’Olne (chief operating officer, editorial content of Euranet Plus), in conversation with author, Brussels, Belgium, 20 May 2014.

${ }^{38}$ Ibid, 2014.

39

${ }^{40}$ Interview with Mareike Roewekamp (project manager, administrative office of Euranet Plus), in conversation with author, Paris, France, 28 May 2014.

${ }^{41}$ French BFM radio' 500 million Europeans is an example of a such talk-show.
} 
which takes place in the European Parliament in Brussels. Its purpose is to connect decision makers with European citizens. ${ }^{42}$

Today, Euranet Plus claims that they have 20 million listeners per day and includes 15 radio stations broadcasting in 15 countries in 14 languages. ${ }^{43}$ Each of these countries is represented by only one station. There are both private and public radio stations among the Euranet Plus members. For example, RTBF in Belgium, Polskie radio in Poland, and Bulgarian national radio in Bulgaria are public. On the other hand, there are several private member stations as well, for instance, Sky Radio in Estonia, Castilla y Leon in Spain, and BFM in France. In March 2013 Euranet Plus opened a news agency in Brussels. The impression obtained from visiting the Euranet Plus news agency in Brussels, conversations with RTBF (a partner radio station) employees, a representative of the administrative office of Euranet Plus in Paris, is that the new agency in Brussels plays the role of a central news agency through making news and providing content for the network members. Yet another function of the news agency is that it represents the network at the European institutions through establishing connections and participation in events and through representation of the network online. The Euranet Plus news agency in Brussels contributes to the development of a supranational point of view. According to JeanMichel Bos, Editor-in-Chief of Euranet Plus news agency in Brussels, the weekly conferences with network members are helpful in development of a common point of view and a common angle to present the European topics. ${ }^{44}$

The youth audience is also a priority of the Euranet Plus radio network. Since 2013, its news agency in Brussels has produced materials and managed the web-page for the informal initiative of European universities radio network: Euranet Plus Connect (which is not covered by the contract of the EU). "Plus Connect", was created at the same time of Euranet and helps the radio network involve students in debates on European affairs. It includes participation from European universities in Denmark, Estonia, Finland, Germany, Ireland, Lithuania, Poland, Romania, Slovenia, Spain and Sweden. These radio stations can also provide local coverage. For example, radio Moreeni in Finland, which belongs to Radio University, is also a local radio station. Their frequency serves approximately 300.000 potential listeners in Tampere, Finland and the surrounding area.

Technically, Euranet Plus Connect is independent from Euranet Plus, however as Mareike Roewekamp said, they "work under one brand... it is not in the frame of the contract but we provide help to this initiative". ${ }^{45}$ According to D'Olne, Euranet Plus still works with universities and plans to increase the presence of students in social media, for example, on behalf of Euranet Plus and to develop something in the academic field. ${ }^{46}$ Euranet Plus has some projects in developing Masters programs in European journalism. In the next section, the results of the

\footnotetext{
${ }^{42}$ Interview with Mareike Roewekamp, in conversation with author, 2014.

${ }^{43}$ Euranet Plus members: Belgium - RTBF radio; Bulgaria - Bulgarian national radio; Croatia - HRT - Croatian radio; Estonia - Sky radio; France - BFM, Germany - AMS-NET; Greece - Skai radio, Hungary - MTVA Magyar radio, Italy - Radio24 - Ilsole24Ore; Latvia - Latvijas Radio; Poland - Polskie radio; Portugal - Renascenca;

Romania - Romanian national radio; Slovenia - radio Slovenia International; Spain - Castilla y Leon.

${ }^{44}$ Interview with Jean-Michel Bos (Editor-in-Chief of Euranet Plus news agency in Brussels), in conversation with author, Brussels, Belgium, 21 May 2014.

${ }^{45}$ Interview with Mareike Roewekamp, in conversation with author, 2014.

${ }^{46}$ Interview with Dominique D’Olne, in conversation with author, 2014.
} 
analysis of the institutional models of Euronews and Euranet Plus will be applied to test the main research hypothesis that Euronews provided institutional learning for Euranet Plus with the European Commission as the vehicle.

\section{Institutional learning}

There is no direct connection between Euronews and Euranet Plus. They are two separate organizations. Their projects and their relations with the European Commission are also different, as are the philosophies. ${ }^{47}$ The main difference between the two is that Euronews covers world news, including European news, from a supranational point of view. In contrast, Euranet Plus radio members covers mostly local European news and broadcast only 75 minutes of news with a European point of view weekly. Roewekamp pointed out that both initiatives came from the European Commission. According to Roewekamp, "the models are different, and the media are different". 48

Table 1. Commonalties and Differences between Euronews and Euranet Plus

\begin{tabular}{|l|l|}
\hline \multicolumn{1}{|c|}{ Commonalities } & \multicolumn{1}{|c|}{ Differences } \\
\hline $\begin{array}{l}\text { Media established by several European } \\
\text { broadcasters }\end{array}$ & $\begin{array}{l}\text { The Euronews model involves European and non- } \\
\text { European broadcasters as shareholders. } \\
\text { Euranet Plus is a network of European broadcasters } \\
\text { working under the same brand. }\end{array}$ \\
\hline Transnational European media & $\begin{array}{l}\text { Euronews is a transnational television channel. } \\
\text { Euranet Plus is a transnational network of national } \\
\text { radios in 15 Member States. }\end{array}$ \\
\hline Headquarters in France & $\begin{array}{l}\text { Euronews headquarters is located in Lyon. } \\
\text { Euranet Plus headquarters is located in Paris. }\end{array}$ \\
\hline News bureau in Brussels & $\begin{array}{l}\text { Euronews opened its bureau in Brussels in June 2011. } \\
\text { Euranet Plus opened a bureau in Brussels in March } \\
\text { 2013 but it operates as a news agency on European } \\
\text { affairs. }\end{array}$ \\
\hline $\begin{array}{l}\text { Broadcasting news with a European } \\
\text { point of view is not the main stream }\end{array}$ & $\begin{array}{l}\text { Euronews is specialized in international news seen by } \\
\text { European journalists. The Brussels bureau provides a } \\
\text { European point of view. } \\
\text { Euranet Plus radio members are national radio } \\
\text { stations that broadcast 75 minutes of news with a } \\
\text { European point of view weekly. }\end{array}$ \\
\hline $\begin{array}{l}\text { Creation and broadcasting of news } \\
\text { from a European point of view } \\
\text { address national audiences in their own } \\
\text { languages }\end{array}$ & $\begin{array}{l}\text { Euronews broadcasts the EU institutional news, more } \\
\text { frequently since the Brussels bureau was opened. } \\
\text { Euranet Plus radio broadcasts European institutional } \\
\text { news daily/weekly in various program formats. }\end{array}$ \\
\hline & $\begin{array}{l}\text { Euronews has daily current news on European affairs } \\
\text { and also programs on regional policy. In general, } \\
\text { there are the same programmes in 13 languages. } \\
\text { Euranet Plus radio members have a variety of }\end{array}$ \\
\hline
\end{tabular}

\footnotetext{
${ }^{47}$ This argument is based on the author's conducted interviews in 2014 with D'Olne, a source in the European Commission, Lir, Loktev, Roewekamp and Simmen.

${ }^{48}$ Interview with Mareike Roewekamp, in conversation with author, 2014.
} 


\begin{tabular}{|l|l|}
\hline & $\begin{array}{l}\text { programs on European affairs titled differently and } \\
\text { they have a different content. }\end{array}$ \\
\hline Existence of the internal and external & $\begin{array}{l}\text { Euronews has an internal editorial line and there is no } \\
\text { editorial line }\end{array}$ \\
& $\begin{array}{l}\text { Eefinition on what is a news on European affairs. } \\
\text { stated in the contract of the European Commission. }\end{array}$ \\
\hline
\end{tabular}

If there is no direct connection between Euronews and Euranet Plus, institutional learning still occurred, from Euronews practice to Euranet Plus. Euronews practice has been taken by the European Commission as a basis for a further development of transnational media on European affairs. Institutional learning became possible through the European Commission policy documents for audiovisual networks on European affairs. The European Commission policy documents Communicating Europe in Partnership (EC 2007a) and Communicating Europe through audiovisual media (EC 2008a) had objectives to accelerate the creation of audiovisual media with a European agenda.

It is very noticeable that the European Commission made use of the Euronews practice in these policy documents and finally came up with a new model of a European broadcaster. Based on existing practice, the European Commission formulated a set of proposals for audiovisual networks and in particular for a European radio network. The Euronews practice has been addressed directly and indirectly in European media studies, and was included in European citizens' surveys. Euronews provided institutional learning for Euranet Plus with the European Commission as the vehicle. The second contract of services with the European radio network started with the creation of a news agency in Brussels. The Euronews opened its Brussels bureau in 2011 only two years before the Euranet Plus followed suit in 2013.

\section{Potential weaknesses of the European radio project}

Based on an analysis of the European radio project, a comparative analysis of Euranet Plus and Euronews practices, a study of the European Commission policy documents for creating audiovisual media networks, as well as interviews with practitioners, I have identified several potential weak points of the European radio network project. Euranet Plus is the latest and the most significant European Commission' project in this area.

Changing several points in the second contract with the Euranet Plus network in 2013, the European Commission was guided by the financial considerations and by the intention to clarify what is news with European agenda, a supranational news to cover. However, these changes of the contract requirements first considered as advantages, carry a risk of becoming drawbacks in the future. As it was pointed out by one of the observers, some former network members complained that at the beginning, when the Euranet radio network had just been established, there were no rules. The requirement of a strict editorial line on European news can lead to an incomplete coverage of European affairs, loss of interest to European news and as a result withdrawing of citizens from media debates and a loss of trust in national media; a loss of journalistic interest to cover news on European affairs. The requirement of having an audience of 300,000 listeners per day for a radio network member can lead to a loss of radio members and a presence of network not in all EU Member States. The interference of the European Commission and the European Parliament can lead to a loss of freedom to express independent points of view by radio members on European affairs, and also to a loss of independence from the European 
institutions. In the situation when these issues are aggravated with the other challenges described by Trenz (2008, 57-58), which are "the entertainment value of EU is low", "citizens do not accept news from Brussels seriously", "cynical public requires more negative news", the probability of the aforementioned risks can be higher and lead to more serious consequences.

\section{Next steps}

The current contract of the European Commission with Euranet Plus is being implemented until 2018, and it is hard to predict whether the requirements of the contract will remain the same or not. As it was concluded by a source in the European Commission yet it is not clear what will be other steps on the way of development of the European public sphere and audiovisual media. ${ }^{49}$ Shirin Wheeler, Spokesperson of the Commissioner of the Commission of the Regions, ${ }^{50}$ said that having been in the European Commission for a few years, she can say that the Commission is asking right questions now, focusing on debates, rather than propaganda, but asking what people care about. Wheeler believes that "media networks do play an important role in the development of a public sphere because this how people get most of their information. Like the EU itself the media networks need to reflect particular interests and particular cultures of the EU". ${ }^{1}$

\section{Conclusion}

In this article, I have examined two transnational audiovisual media on European affairs which are supported by the European Commission. The main hypothesis of this study has been supported: Euronews and Euranet Plus as audiovisual transnational media represent an effort to foster the development of the European public sphere. Euronews and Euranet Plus contribute to the development of the European public sphere mostly through initiating debates on European affairs with the involvement of the civil society and the youths of the European Union, developing the feeling among Europeans that the EU is their common cause, discussing different topics of European integration. Euronews provided institutional learning for Euranet Plus with the European Commission as the vehicle. Institutional learning became possible through the European Commission policy documents for audiovisual networks on European affairs which are based on Euronews practices. As can be seen, Euronews has been functioning for over 20 years and it is a dynamic structure. Euronews changes its priorities following new challenges, and new priorities of the European public sphere. The study highlighted the importance of further research on the role of transnational audiovisual media on European affairs in the development of the European public sphere, in particular during the elections campaign for the 2019 European Parliament Elections.

\footnotetext{
${ }^{49}$ Interview with a source in the European Commission, in conversation with author, 2014.

${ }^{50}$ Interview with Shirin Wheeler (Spokesperson of the Commissioner of the Commission of the Regions), in conversation with author, Brussels, Belgium, 26 May 2014.

${ }^{51}$ Ibid, 2014.
} 


\section{References}

Baisnee, Olivier. 2007. "The European Public Sphere Does Not Exist (At Least It's Worth Wondering...).” European Journal of Communication 22 (4): 493-503.

Baisnee, Olivier, \& Marchetti, Dominique. 2000. "Euronews, un laboratoire de la production de l'information "europeenne". Culture et Conflits 38-39: 2-19. http://conflits.revues.org/index283.html

Bee, Cristiano. 2008. “The 'Institutionally Constructed' European Identity: Citizenship and Public Sphere Narrated by the Commission." Perspectives on European Politics and Society 9 (4): 431-450.

Bentele, Gunter, \& Nothhaft, Howard. 2010. "Strategic Communication and the Public Sphere from a European Perspective.” International Journal of Strategic

Communication 4: 93-116. doi: 10.1080/15531181003701954.

Brüggemann, Michael, \& Schulz-Forberg, Hagen. 2008. “Towards a Pan-European Public Sphere? A Typology of Transnational Media in Europe" (chpt. 5). In Transnationalization of Public Spheres, edited by Hartmut Wessler, Bernhard Peters, \& Michael Brüggemann, 78-94. New York, NY: Palgrave Macmillan.

Butsch, Richard. 2007. Media and Public Sphere. New York, NY: Palgrave Macmillan.

Castells, Manuel. 1997. The Rise of the Network Society. Malden, MA: Blackwell.

Cerutti, Furio. 2003. “A political identity of the Europeans?” Thesis Eleven 72 (1): 26-45.

Chalaby, Jean K. 2002. "Transnational Television in Europe: The Role of Pan-European Channels.” European Journal of Communication 17 (2): 183-203. . 2005. "From internationalization to transnationalization." Global Media and Communication 1 (1): 28-33.

Eriksen, Erik O. 2005. “An emerging European public sphere.” European Journal of Social Theory 8 (3): 341-363.

2007. "Conceptualising European public spheres. General, segmented and strong publics" (chpt. 2). In The European Union and the Public Sphere. A communicative space in the making?, edited by John Erik Fossum, \& Philip Schlesinger, 23-43. New York, NY: Routledge,

Euroalert. 2013. Production and broadcast of radio programmes on EU affairs, on air and on digital platforms, by a network of EU radio broadcasters [EU Tender]. http://euroalert.net/en/contracts.aspx?idl=1841666. Accessed 6 January 2015 
2014. Euronews Media Kit 2014 [Media Kit].

http://www.euronews.com/media/download/mediapack/2014-03-

MEDIA-KIT-ENGLISH.pdf

Eurobarometer surveys 73-80. 2010-2013. Public opinion in the European Union.

August 2010 - November 2013.

European Commission. 2005, October 13. Plan D for Democracy, Dialogue and

Debate. COM (2005) 494.

. 2006, February 1. White Paper on a European Communication Policy.

$\operatorname{COM}(2006) 35$ final.

2007a. Communicating Europe in Partnership. COM(2007)

569 final, \{SEC (2007) 1265\}, \{SEC(2007) 1267\}.

. 2007b. Communicating Europe via the Internet - Being Global, Going

Local, \{SEC(2007) 1742\}.

. 2008a, April 24. Communicating Europe through

audiovisual media, \{SEC(2008) 506/2\}.

. 2008b, November 11. Europe on the airwaves... and on the

Web: launch of the EURANET European Radio Network on-line platform. IP08-1680. Retrieved 19 January 2014 from http://europa.eu/rapid/press-

release_IP-08-1680_en.htm

. 2009, November 11. Green Paper on a European Citizens'

Initiative. COM(2009) 622 final.

. 2013, May. European Youth: Participation in Democratic

Life. Flash Eurobarometer \#375.

Firmstone, Julie. 2008. "Approaches of the transnational press to reporting Europe."

Journalism 9 (4): 423-442. doi:10.1177/1464884908091293.

Fougier, Eddy. 2009. “Les Français et la télévision face à l'Europe: le grand malentendu?" Questons d'Europe 128. Fondation Robert

Schuman website: http://www.robert-schuman.eu/fr/questions-d-europe/0128les-francais-et-la-television-face-a-1-europe-le-grand-malentendu

Fraser, Nancy. 2007. "Transnationalizing the Public Sphere: On the Legitimacy and Efficacy of Public Opinion in a Post-Westphalian World." Theory, Culture \& Society 24 (4): 7-30. doi: 10.1177/0263276407080090. 
Garcia-Blanco, Inaki, \& Cushion, Stephen. 2010. “A partial Europe without citizens or EU-level political institutions. How far can Euronews contribute to a European public sphere?" Journalism Studies 11 (3): 393-411.

Doi: 10.1080/14616700903378653.

Gardoso, Gustavo. 2008. "From Mass to Networked Communication: Communicational Models and the Informational Society." International Journal of Communication 2: 587-630.

Gripsrud, Jostein. 2007. "Television and the European Public Sphere.” European Journal of Communication 22 (4): 479-492.

Grundmann, Reiner. 1999. "The European public sphere and the deficit of democracy." The Editorial Board of The Sociological Review 48 (S1): 125-146.

Habermas, Jurgen. 1989. The Structural Transformation of the Public Sphere. Cambridge: Polity Press.

Heller, Maria, \& Renyi, Agnes. 2007. "EU enlargement, identity and the public sphere" (chpt. 9). In The European Union and the Public Sphere. A communicative space in the making?, edited by John Erik Fossum, \& Philip Schlesinger, 169-186. NY: Routledge.

Harrison, Jackie, \& Wessels, Bridgette. 2009. Mediating Europe: New media, mass communications and the European public sphere. New York and Oxford: Berghahn Books.

Kaitatzi-Whitlock, Sophia. 2007. "The missing European public sphere and the absence of imagined of imagined European citizenship.” European Societies 9 (5): 685-704.

Kaliberda, Elena. (2015, March). The European Public Sphere in the Era of Euroscepticism. The European Commission initiatives on creating transnational media networks. Paper presented at the $10^{\text {th }}$ Annual Graduate Student Conference on the European Union of University of Pittsburgh, USA.

Kantner, Cathleen. 2006. "Collective identity as shared ethical self-understanding." European Journal of Social Theory 9 (4): 501-523.

Kohler-Koch Beate, \& Eising Rainer. 1999. The transformation of governance in the European Union. London, New-York, N.Y.: Routledge, 8-13.

Kurpas, Sebastian, Clerck-Sachsse, Julia, \& Brüggemann, Michael. 2006. Informing European Citizens? Evaluating the Activities of the European Commission in the field of Information. Study commissioned by the European Parliament Budget Committee. 31 August 2006. Centre for European Policy Studies, http://www.ceps.be/book/informing-european-citizens 
Lauristin, Marju. 2007. "The European Public Sphere and the Social Imaginary of the 'New Europe'.." European Journal of Communication 22 (4): 397-412. doi: $10.1177 / 0267323107083058$.

Lecheler, Sophie. 2008. "EU membership and the press." Journalism 9 (4): 443-464. doi: $10.1177 / 1464884908091294$.

Levy, David. 1999. "Regulating access to Digital Broadcasting: The Advanced Television Standards Directive" (chpt 4). In Europe's Digital Revolution: Broadcasting Regulation, the EU and the nation State, 58-75.USA, NY: Routledge.

Loktev, Denis. 2008. Organizacia raboty evropeiskogo informacionnogo kanala Euronews [Organization of work of the European news channel Euronews]. Moscow, Russia: Lomonosov Moscow State University.

2012. Identity vs. neutrality in the editorial policies of transnational news channels. PhD diss. France, Lyon: Université Lumière. http://www.loctier.com/identity-vsneutrality-in-the-editorial-policies-of-transnational-news-channels/

Machill, Marcel. 1998. "Euronews: The first European news channel as a case study for media industry development in Europe and for spectra of transnational journalism research." Media, Culture \& Society 20 (3): 427-450.

Machill, Marcel, Beller, Marcus, \& Fischer, Corinna. 2006. “Europe-Topics in Europe's Media: The Debate about the European Public Sphere: A Meta-Analysis of Media Content Analyses." European Journal of Communication 21 (1): 57-88. doi: $10.1177 / 0267323106060989$.

McCarthy, Thomas. 1989. Introduction. In The Structural Transformation of the Public Sphere, by Jurgen Habermas, xi. Cambridge, UK: Polity Press.

Metykova, Monika, \& Preston, Paschal. 2009. “An Elusive European Public Sphere: The Role of Shared Journalistic Cultures." In Media in the Enlarged Europe, edited by A. Charles, 6168. U.S.: Intellect Bristol.

Nieminen, Hannu. 2008. "Europe of networks or the European public sphere? Four plus one approaches." Sociology. Thought and Action 3 (23): 10-27.

Neidhardt, Friedhelm et al. 2000. "Konstitutio nsbedingungen politischer Öffentlichkeit: Der Fall Europa [Conditions for the Constitution of a European Public Sphere]'. In Zur Zukunft der Demokratie. Herausforderungen im Zeitalter der Globalisierung edited by HansDieter Klingemann \& Friedhelm Neidhardt, 1-26. Germany, Berlin: Sigma.

Nitoiu, Cristian. 2013. "The European Public Sphere: Myth, Reality or Aspiration?" Political Studies Review 11 (1): 26-38. doi: 10.1111/j.1478-9302.201.00287.x 
Papathanassopoulos, Stylianos, \& Negrine, Ralph. 2011a. "Public Communication in Europe: Constructing Europe and the European Public Sphere" (chpt 7) In European Media: Structures, Policies and Identity, 123-149. UK: Polity Press.

. 2011b. "Media and European Identity", in European Media: Structures, Policies and Identity, 150-169. UK: Polity Press.

Peters, Bernhard, Sifft, Stefanie, \& Wimmel, Andreas. 2005. "7 National and transnational public spheres: the case of the EU." European Review, 13 (1): 139-160.

PoliPedia.eu. 2014. Is there something like a European identity? [Web log post]. http://www.polipedia.eu/tiki-index.php? Accessed 16 October 2014. page=Surveys+about+European+identity\%3A+the+case+of+Eurobarometer

Polskie radio. 2009, May 27. Declaration of Pan-European cooperation and communication. http://www2.polskieradio.pl/euranet/_doc/Warsaw_Declaration.PDF Accessed 17 February 2015.

Preston, Paschal. 2009. “An Elusive Trans-national Public Sphere?” Journalism Studies 10 (1): 114-129. doi: 10.1080/14616700802560591

Raupp, Juliana. 2004. "The public sphere as central concept of public relations". In Public Relations and Communication Management in Europe, edited by Betteke Ruler, \& Dejan Verčič, 309-315. Berlin-New-York: Mouton de Gruyter.

Reeves, Madeleine. 2014. Border works: spatial lives of the state in rural Central Asia. Ithaca, NY: Cornell University Press.

Rowland, Wade. 2006. Spirit of the Web. The age of Information from Telegraph to Internet. Toronto: Thomas Allen Publishers.

Schiller, J. Zach. 2007. "On Becoming the Media: Low Power FM and the Alternative Public Sphere". In Media and Public Spheres, edited by R. Butsch, 122-135. NY: Palgrave Macmillan.

Statham, Paul. 2011. "The Emergence of a Public Sphere for the European Union: What Prospects for Transnationalism?" In Transnational Europe: promise, paradox, limits, edited by Joan DeBardeleben, \& Achim Hurrelmann, 77-95. Houndmills, Basingstoke, Hampshire, UK; New York: Palgrave Macmillan.

Thiel, Michael. 2008. "European Public Spheres and the EU's Communication Strategy: From Deficits to Policy Fit?" Perspectives on European Politics and Society 9 (3): 342-356. doi: 10.1080/15705850802223457. 
2012, July. European Public Spheres and the European Union Communication Strategy:

From Deficits to Policy Fit? [Web log post]. Social Science Research Network website:

http://ssrn.com/abstract=2099664

Trenz, Hans Jorg. 2007.'”'Quo vadis Europe?"' Quality newspapers struggling for European unity." In The European Union and the Public Sphere. A communicative space in the making?, edited by John Erik Fossum, \& Philip Schlesinger, 89-109. NY: Routledge.

. 2008. "Media: the unknown player in European integration" (chpt. 2). In

Media, Democracy and European Culture, edited by Ib Bondebjerg, \& Peter Madsen, 49-

64. Bristol, UK: Intellect Books,

Veltri, Giuseppe. 2012. "Information flows and centrality among elite European newspapers." European Journal of Communication 27 (4): 354-375.

Venturelli, Shalini. 1993. "The imagined transnational public sphere in the European community's broadcast philosophy: Implications for democracy." European Journal of Communication 8 (4): 491-518.

Volkmer, Ingrid. 2008. "Satellite cultures in Europe: Between national spheres and a globalized space." Global Media and Communication 4 (3): 231-244. doi: 10.1177/1742766508096079.

Wessler, Hartmut, \& Brüggemann, Michael. 2007. "The Quest for a European Public Sphere: News Media and Democratic Legitimacy" (chpt. 5). In Democratic dilemmas of multilevel governance: legitimacy, representation and accountability in the European Union, edited by Joan DeBardeleben, \& Achim Hurrelmann, 94-116. NY: Palgrave Macmillan.

\section{Interviews}

Bos, Jean-Michel. 2014, May 21. Interview with the Editor-in-Chief of the Euranet Plus News agency. Brussels, Belgium. Archive of the interviewer E. Kaliberda.

D'Olne, Dominique. 2014, May 20. Interview with the Chef des Rédactions of Radio RTBF, the Chief operating officer for editorial content of Euranet Plus. Brussels, Belgium. Archive of the interviewer E. Kaliberda.

European Commission source. 2014, May 26. Interview with the representative of the European Commission. Brussels, Belgium. Archive of the interviewer E. Kaliberda.

Lir, Albina. 2014, May 30. Interview with the Strategic Planning Editor of Euronews. Lyon-Ecully, France. Archive of the interviewer E. Kaliberda.

Loktev, Denis. 2014, May 30. Interview with the Senior Producer of Euronews. Lyon-Ecully, France. Archive of the interviewer E. Kaliberda. 
Palokaj, Augustin. 2014, May 26. Interview with the Chief of Croatian newspaper Jutarhji List bureau in Brussels. Brussels, Belgium. Archive of the Interviewer E. Kaliberda.

Parizot, Stéphane. 2014, May 30. Interview with the Deputy Editor-in-Chief of Euronews. Lyon-Ecully, France. Archive of the interviewer E. Kaliberda.

Roewekamp, Mareike. 2014, May 28. Interview with the Project Manager of the Administrative office of Euranet Plus. Paris, France. Archive of the interviewer E. Kaliberda.

Simmen, Jan. 2014, May 21. Interview with the Management/Strategy Chief of Euranet Plus. Brussels, Belgium. Archive of the interviewer E. Kaliberda.

Wheeler, Shirin. 2014, May 26. Interview with the Spokesperson of the Commissioner of the Commission of the Regions of the European Commission. Brussels, Belgium. Archive of the interviewer E. Kaliberda. 
Published by the Centre for European Studies at Carleton University, Ottawa, Canada Available online at: journals.carleton.ca/rera/index.php/rera

RERA is an electronic academic peer-reviewed journal. Topics relate to the European Union, its Member States, the former Soviet Union, and Central and Eastern Europe. The journal is a joint project supported by the Canada-Europe Transatlantic Dialogue-a cross-Canada research network supported by the Social Sciences and Humanities Research Council of Canada (SSHRC) - along with the Institute of European, Russian and Eurasian Studies (Carleton University) and its associated research unit, the Centre for European Studies.

RERA aims to provide an accessible forum for research, to promote high standards of research and scholarship, and to foster communication among young scholars.

\section{Contact:}

Carleton University

The Centre for European Studies

1103 Dunton Tower

1125 Colonel By Drive

Ottawa, ON K1S 5B6

Canada

E-mail: rera-journal@ carleton.ca

\section{Creative Commons License}

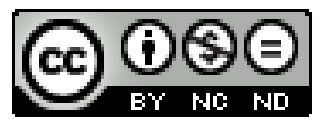

creativecommons.org/licenses/by-nc-nd/3.0

This Working Paper is licensed under a Creative Commons Attribution-Non-CommercialNo Derivs 3.0 Unported License (CC BY-NC-ND 3.0).

Articles appearing in this publication may be freely quoted and reproduced, provided the source is acknowledged. No use of this publication may be made for resale or other commercial purposes.

ISSN: $1718-4835$

(C) 2017 The Author(s) 